\title{
Survival of the Malaysian initial public offerings
}

\author{
Wahidah Shari ${ }^{*}$
}

${ }^{a}$ Islamic Business School, College of Business, Universiti Utara Malaysia (UUM) 06010 Sintok, Kedah, Malaysia

\begin{tabular}{l}
\hline C H R O N I C L E \\
\hline Article history: \\
Received: October 18, 2018 \\
Received in revised format: No- \\
vember 11, 2018 \\
Accepted: January 3, 2019 \\
Available online: \\
January 3, 2019 \\
\hline Keywords: \\
IPOs \\
Survival \\
Going public \\
\hline
\end{tabular}

\author{
A B S T R A C T
}

\begin{abstract}
This study addresses the extent to which Malaysian public listed firms survive after the IPO. The result reports that $7.72 \%$ of Malaysian IPOs were delisted from the market after five years, which is lower than the delisting rate reported in previous studies in developed markets. The delisting rate increased to $13.2 \%$ after seven years of listing. Further investigation shows that an unsatisfactory financial condition is the primary factor of failure. Comparison of the survival rate between the Main Market and the ACE market reveals that the cumulative survival rates over one through seven years after the IPO are consistently higher for the Main Market IPOs than the ACE Market IPOs, suggesting that the ACE Market IPOs have a higher probability to be delisted from the Market compared with the Main Market IPOs.
\end{abstract}

C 2019 by the authors; licensee Growing Science, Canada

\section{Introduction}

In recent year, the survival of public companies after the IPO has gained attention among academic researchers. The survivors in this study were defined as companies that continued to be listed in the Market or companies that have been transferred to other Markets ${ }^{i}$ as of December 31, 2017. Companies delisted for any other reasons were considered as non-survivors. Treating market transfer as survivors is consistent with Espenlaub et al. (2012) while the decision to treat companies that had been delisted due to merger and acquisition was consistent with Jain and Kini (2000).

Research on the IPO survival has largely focused on examining the survival of IPO in developed Markets (see, for example, Hensler et al., 1997; Fama \& French, 2004; Bradley et al., 2006; Jain \& Kini, 2008). Empirical studies, however, showed a substantial variation in the survival rate between countries and periods (See Table 1). Results reported by Schultz (1993) showed that between 12\% and 42\% of the US IPOs were delisted from the Market after three years of their listing. Fama and French (2004) documented an increase in the failure rates of US newly listed firms over the past several decades. They further argued that the increase in the failure rate of the newly listed firms was due to the changes in the characteristics of newly listed firms in a recent period.

\footnotetext{
* Corresponding author.

E-mail address: wahidah@uum.edu.my (W. Shari)

(C) 2019 by the authors; licensee Growing Science, Canada doi: $10.5267 /$ j.msl.2019.1.002
} 
Due to the limited attention given to the emerging market, this paper fills a gap by examining the survival rates of Malaysian IPO listed between 2002 and 2010. Investigating the ability of a new issue's survival is essential as it complemented the performance analysis of public listed companies (Welbourne \& Andrews, 1996; Audretsch \& Lehmann, 2005). Caves (1998) considered the ability of the newly listed firms to survive over time as a positive performance and non-survival as a negative performance. In particular, this paper addresses the issue of the extent to which Malaysian public listed companies survived after the IPO.

Examination of the post-IPO survival in Malaysian market is important for at least two reasons. First, in Malaysia, survival of the public companies after the IPO is of great concern to the regulatory bodies. For example, in 2001, Bursa Malaysia developed a framework for the public companies under Practice Note 4 (PN4) and Practice Note 10 (PN10) (Securities Commission Malaysia, 2005). The framework has a provision that states that the public listed companies that are facing financial problems or have an inadequate level of operations should disclose sufficient information regarding the matter to Bursa Malaysia. Bursa Malaysia can monitor these companies closely and ensure that these companies take immediate actions for restructuring to address their unsatisfactory conditions, and hence, continue to survive as public companies. Second, most of the previous Malaysian studies that measured the longterm performance of IPO found that Malaysian IPOs outperformed in the long-term period (See, for example, Paudyal et al., 1998; Jelic et al., 2001; Corhay, 2002; Ahmad-Zaluki et al., 2007; How et al., 2007; Abu Bakar \& Rosbi, 2016) ${ }^{\mathrm{ii}}$. Gregory et al. (2010) documented that poor long-term performance of AIM IPOs resulted in a higher failure rate. Given the positive long-term performance of Malaysian IPOs, this study expects that Malaysian IPOs would survive longer than those in other markets such as the US and the UK that have commonly reported poor long-term performance and high failure rates.

Based on an extensive literature search, this is the first study that investigates post-IPO survival in the Malaysian Market. Moreover, this study used more recent samples of Malaysian IPO listed between 2002 and 2010. The data for each company were traced until December 31, 2017. IPO companies that continued trading until the date was considered as right censored. This issue is particularly important as it can help investors evaluate and predict the survival of public companies, particularly in the Malaysian Market. The plan for this paper is as follows. The next section review the previous literature of the post-IPO survival in various countries. Section 3 and Section 4 present data sources and methodology used in this study, respectively. The study presents the results in Section 5. The summary and conclusion are provided in the final section.

\section{Literature review}

There is an established body of literature on the survival of newly listed stocks in the developed market such as the US and UK. Table 2 and Table 3 present the delisting rate of IPO in various countries. Overall, the delisting rate of the newly listed firms varies between the market, sample period and stratification of sample criteria (Espenlaub et al., 2012). Among the earliest, Schultz, (1993) examined the survival of 797 units (bundles of common stock and warrants) and share IPOs issued in the US during the period of 1986-1988. He predicted that firms that issue units had a higher probability to be delisted because firms that go public via units are typically smaller, younger, and riskier than those go public via share IPOs. He found that in over three years, $12 \%$ to $42 \%$ of the US IPO were delisted from the market. Similarly, Hensler et al. (1997) found that survival time for 741 US IPOs increases with firm size, firm age, initial return, percentage of insider ownership and IPO activity level in the market.

Seguin and Smoller (1997) compared the survival rate of penny stock ${ }^{\text {iii }}$ and non-penny stock IPO coming to the market from 1974 to 1988 . They found that penny stocks IPO had a higher probability of being delisted from the market compared to the non-penny stocks. This finding was confirmed by Bradley et al. (2006) who documented that the penny stock ${ }^{\text {iv }}$ IPOs had a significantly higher percentage $(51.4 \%)$ of delisting than ordinary IPOs $(14.3 \%)$ within five years following the IPO. They further 
argued that the most common reasons for the delisting are an insufficient capital, low stock price, delinquencies in the filing, or non-payment fees. Fama and French (2004) added to the previous works conducted in the US market by developing a detailed picture of how the changing characteristics of NASDAQ new listed stocks affect the firms' survival. They documented that the probability of the firm to survive in the first ten years reduced from $61 \%$ in 1973 to only $37 \%$ in 1991 . They suggested that a higher delisting rate in the later period is due to the changes in the profile of the firms listed in the market. Using 6,235 U.S IPO samples listed during 1985-2005, Kooli and Meknassi (2007) examined whether firm-specific and issuing-specific characteristics had an impact on the probability of the firms survival in the long-term. The study reported that, after five years of the IPO, $55.18 \%$ of IPO firms were successfully surviving, $24.59 \%$ were acquired, and $20.23 \%$ of IPO firms were delisted due to other negative reasons. Their multinomial logit model suggests that the firm-specific and issuing-specific characteristics of the IPO firm had a significant effect on determining the survival rate of the IPO firms. Focusing on high-tech IPOs, Demers and Joos (2007) reported that those firms maintained a lower delisting rate than other IPOs. They also found that only $9 \%$ of their high-tech IPO samples were delisted compared with the $17 \%$ of other sectors' IPO in five years. In a more recent study, Chou et al. (2013) documented that 13\% of the US IPO listed during 1980-2003 failed to continue being listed after a five-year period. This figure, however, is lower than the failure rate reported in the previous USbased studies such as by Hensler et al. (1997) (28\%), Jain and Kini (2000) (26\%), Kooli and Meknassi (2007) (45\%), and Jain and Kini (2008) (35\%). In the UK, the failure rate of newly listed companies is slightly higher than the failure rate reported in the US market. On average, more than $40 \%$ of the UK IPO were delisted from the market within five years after the issuing date. For example, Espenlaub et al. (2012) examined the survival rate of the Alternative Investment Market (AIM) listed between 1995 and 2004. They found that 59 of the AIM IPOs had survived for over five years. This implies that $41 \%$ of the IPO were delisted from the AIM. In comparison, Ahmad and Jelic (2014) found that the five years cumulative survival rate for Main Market IPOs listed from 1990 to 2006 in the London Stock Exchange (LSE) was 69\%, which is higher than the survival rate of the AIM market (59\%) as reported by Espenlaub et al. (2012).

Table 1

The Delisting Rate of IPOs in Various Countries

\begin{tabular}{|c|c|c|c|c|c|}
\hline Country & $\begin{array}{l}\text { Period of } \\
\text { study }\end{array}$ & $\begin{array}{l}\text { Sample } \\
\text { Size }\end{array}$ & $\begin{array}{l}\text { 3-years delisting } \\
\text { rate }(\%)\end{array}$ & $\begin{array}{c}\text { 5-years delisting rate } \\
(\%)\end{array}$ & Author(s) \\
\hline Australian & 1994-2002 & 125 & - & 26 & Chancharat et al. (2012) \\
\hline Canada & $1986-2003$ & 2373 & - & 20 & Carpentier \& Suret (2011) \\
\hline Taiwan & $1992-2000$ & 560 & 6.8 & - & Yang \& Sheu (2006) \\
\hline UK & 1995-2004 & 896 & 26 & 41 & Espenlaub et al. (2012) \\
\hline UK & 1990-2006 & 580 & - & 69 & Ahmad \& Jelic (2014) \\
\hline UK & 1998-2008 & 570 & - & 56 & Alhadab et al. (2015) \\
\hline UK & $1975-2004$ & & $\begin{array}{l}1.2 \text { (Main) } \\
4.3 \text { (AIM) }\end{array}$ & $\begin{array}{l}3.6 \text { (Main) } \\
9.5 \text { (AIM) }\end{array}$ & Gregory et al. (2010) \\
\hline US & 1986-1988 & 797 & $12-42$ & - & Schultz (1993) \\
\hline US & $1975-1984$ & 741 & - & 28 & Hensler et al. (1997) \\
\hline US & 1974-1988 & 5896 & - & $\begin{array}{l}47 \text { (penny) } \\
17 \text { (others) }\end{array}$ & Seguin \& Smoller (1997) \\
\hline US & $1977-1990$ & 877 & - & 26 & Jain \& Kini (2000) \\
\hline US & $1973-2001$ & 477 & - & 59 (10-years) & Fama \& French (2004) \\
\hline US & 1990-1998 & 2958 & $6-35$ & - & Bradley et al. (2006) \\
\hline US & $1980-2000$ & 3574 & - & $\begin{array}{l}9 \text { (High-tech) } \\
17 \text { (others) }\end{array}$ & Demers \& Joos (2007) \\
\hline US & $1985-2005$ & 6235 & 24 & 45 & Kooli \& Meknassi (2007) \\
\hline US & 1980-1997 & 3837 & - & 35 & Jain \& Kini (2008) \\
\hline US & $1982-2000$ & 6271 & - & $\begin{array}{l}24 \text { (Internet) } \\
14-18 \text { (other) }\end{array}$ & Bhattacharya et al. (2009) \\
\hline US & $1985-2005$ & 6235 & $\begin{array}{l}7 \text { (high VC) } \\
10 \text { (low VC) }\end{array}$ & & Hamza \& Kooli (2010) \\
\hline US & $1980-2003$ & 2893 & - & 13 & Chou et al. (2013) \\
\hline 4 countries & 1995-2009 & 3755 & - & 42 & Vismara et al. (2012) \\
\hline 32 countries & $2000-2008$ & 7627 & 11 & 22 & Espenlaub et al. (2016) \\
\hline
\end{tabular}


In another country, Yang and Sheu (2006) investigated the survival rate of 560 Taiwan IPO listed over the period 1992-2000. After three years from the listing, they found that $6.8 \%$ of the IPO were delisted from the market. Focusing on the Australian new economy (small firms with high growth opportunity), Chancharat et al. (2012) examined the relationship between the board structure (board size, board independence and dual leadership) and firm survival after the initial trading. Out of 125 IPO samples listed from 1994 to 2002, about $25.6 \%$ were delisted from the market within five years period. Analysis of the effect of the board structure posits that only board independence was statistically significant in increasing the likelihood of the IPO survival. Focusing on Canada's IPOs listed between 1986 and 2003, Carpentier and Suret (2011) revealed that $20 \%$ of the companies were delisted after five years, which was lower than the failure rate reported in the US Market. Espenlaub et al. (2016) investigated the survival rate of IPO from 32 countries (categorised into four regions: North America, Europe, BRICS, and Asia-Pacific). They found that the survival rate of the IPOs varied across countries. They further documented that variations in the survival rate were due to different levels of the legal systems.

\section{Data}

The dataset of this study covers the IPO companies listed on the Malaysian stock exchange (Bursa Malaysia) between 2002 and 2010. The data on IPO companies were downloaded from Bursa Malaysia's website at http://www.bursamalaysia.com. The data on the managing underwriter, net income, date of incorporation, total asset, total liability, long-term liability, paid-up equity, and method of pricing were hand-collected from the prospectuses and annual reports of the companies. After filtering the inaccurate, incomplete, and missing values, the final sample consist of 352 IPOs. Following Espenlaub et al. (2012), this study defines a survivor as a company that remains traded on the market or has been transferred to another market at the end of the period of the study. A non-survivor is defined as a company that was delisted from the market due to the failure to continue complying with the listing requirements, unsatisfactory financial condition, merger and acquisition, or proposed selective capital repayment. For the purpose of this study, the data of the IPO companies listed between 2002 and 2010 are traced up to 31 December 2017. The survival period of each IPO company is observed over a sevenyear period starting from the end of the first trading day as illustrated in Fig. 1 below:

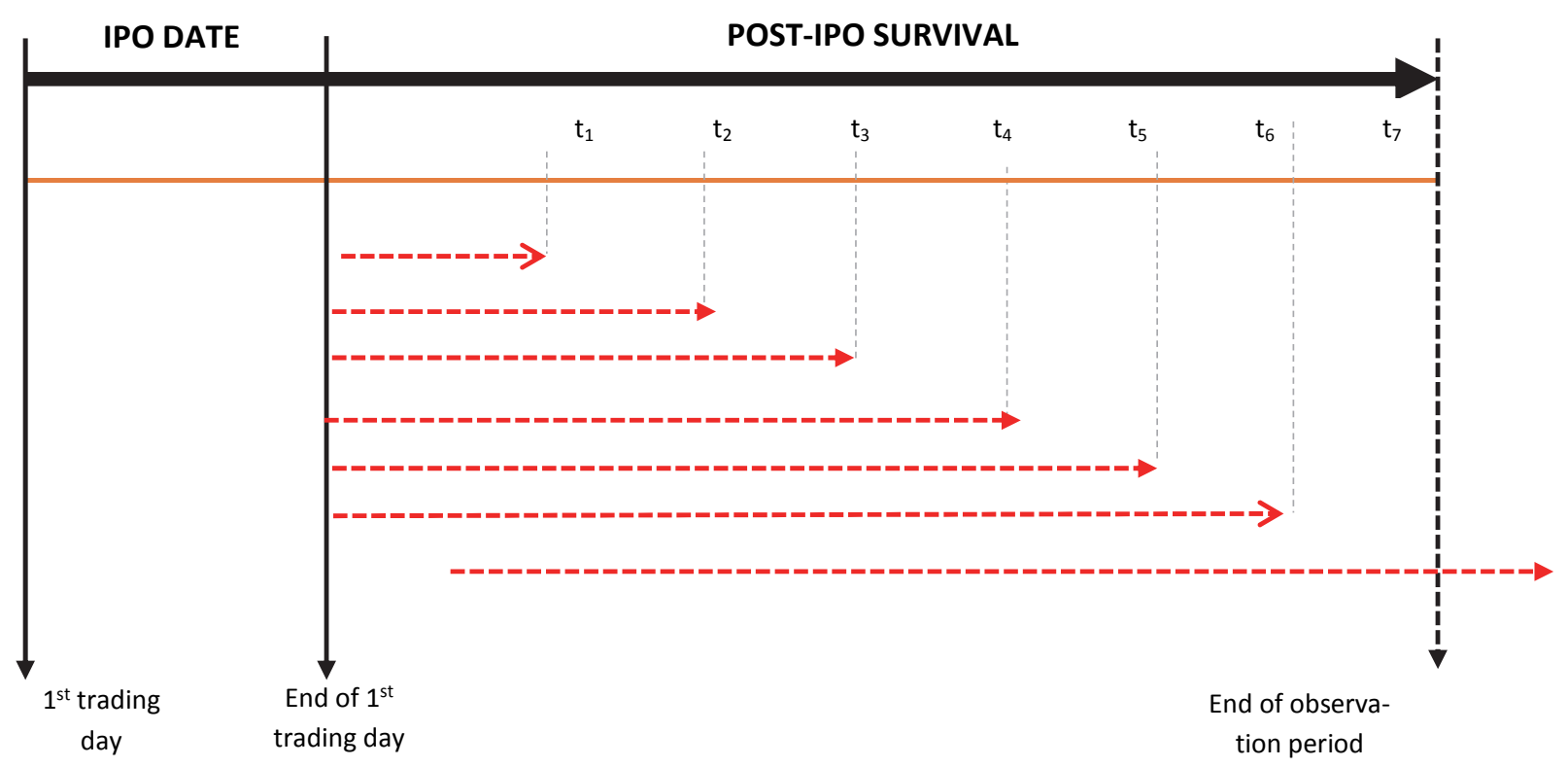

Fig. 1. Time line for Post-IPO Survival 


\section{Methodology}

The IPO companies' survival rates are assessed using a non-parametric estimator of the Kaplan-Meier method. This method takes into account the censoring and other features of the survival data (Cleves et al. 2004). The Kaplan-Meier method is defined as follows:

$$
S\left(t_{j}\right)=S\left(t_{j-1}\right)\left(\frac{n_{j}-d_{j}}{n_{j}}\right),
$$

where $S\left(t_{j}\right)$ is the probability of surviving in month $t_{j}, S\left(t_{j-1}\right)$ is the probability of surviving in month $t_{j-1}, n_{j}$ is the number of IPOs at risk or involved in the study at the beginning of month $t_{j}$, and $d_{j}$ is the number of IPO companies delisted during month $t_{j}$. This study use log-rank test for testing the statistical differences in survival rate between various groups such as across listing years and sectors.

\section{Results}

\subsection{Kaplan-Meier survival rates}

Table 2 provides the cumulative survival rates for one year to seven years after the closing date of the first trading day. The cumulative survival rates were measured using a non-parametric approach of survival analysis known as the Kaplan-Meier method. The analysis of the survival rate of IPOs was conducted for the full samples (PANEL A), according to the listing year (PANEL B), and by sectors (PANEL C). This is because prior research has indicated that the listing year and sectors may affect the firm's survival (Seguin \& Smoller 1997; Espenlaub et al. 2012; Ahmad \& Jelic 2014; Bhattacharya et al. 2015).

The survival rate of the full samples (PANEL A) shows that out of 352 listed companies between 2002 and 2010 , about $99.2 \%$ of the IPOs still survive a year after the IPO. This indicates that about $0.8 \%$ (100-99.2) of the IPO are delisted from the Bursa Malaysia. This figure is lower than the delisting rate reported in the US Market by Schultz 1993; and Kooli and Meknassi (2007). They reported that 2\% to $7 \%$ of US IPOs had been delisted from the Market within one year of being listed. It can be observed from the table that the survival rate of Malaysian IPO drops to $98 \%$ after three years and $92.3 \%$ after five years following the first trading day. These findings are comparable to the recent findings in the study conducted by Espenlaub et al. (2016), who examined the survival rate of the IPOs listed during 2000-2008 in four different regions including North America, Europe, BRICS, and the Asia-pacific. In comparison, the five years post-IPO survival rates $(92.3 \%)$ found in this study is noticeably higher than those found in North America (73.11\%), Europe (61.03\%), and BRICS (81.61\%), but slightly lower than Asia-pacific (93.17\%). Based on the table, another 5.5\% (92.3\%-86.8\%) of IPOs are permanently eliminated from the Bursa Malaysia, leaving a cumulative survival rate of $86.79 \%$ IPOs that successfully survived after seven years.

As indicated in PANEL B of Table 2, the survival rate of the IPO varies slightly across the listing year. The log-rank test that evaluates the equality of survival rates across the listing years is unable to reject the null hypothesis of equality of the survival rates across the listing years with a Chi-Squared value of 9.56 ( $p$-value $=0.297$ ). In particular, the survival rate of the IPO firms listed in 2007, 2008 and 2009 is $100 \%$ within 5 years of listing. This indicates that none of the firms listed during this period was delisted either due to unsatisfactory financial condition, or failing to continue to fulfil the listing requirement, or through merger and acquisition, or proposed selective capital repayment even during the global economic crisis. The cumulative survival rates for 2008 and 2009 remain $100 \%$ towards the end of the seven years observation period. This study predicts that the firms that went public during the global financial crisis are among the low-risk companies. The lowest survival rates are reported by the firms listed in 2003. The cumulative survival rates drop from $96.3 \%$ after three years to $79.63 \%$ after seven years of being listed in the Market. It can be observed that IPO firms listed in 2004 experienced the 
earliest delisting record in which the IPO is listed in the Market for less than one year. Splitting the sample down according to sectors as seen in PANEL C, indicates that the survival rate varies across the sectors. However, the equality test indicates that the variation is statistically insignificant (Chisquare $=10.88$, p-value $=0.2842$ ). Similar findings were also reported by Espenlaub et al. (2012) in the Alternative Investment Market (AIM) in the UK. Table 2 also shows that none of the infrastructure projects and plantation sector are delisted during seven years of observation. This is because these two sectors have received strong support from the Malaysian Government. According to the Eight Malaysia Plan, the Malaysian government has spent about RM64.13 billion for the country's infrastructure development (Naidu, 2008). In Ninth Malaysia Plan, the Malaysian government has allocated an amount of RM11.4 billion to the plantation sector for enhancing productivity, research, and development, land consolidated, and new land development (Economic Planning Unit, 2006). Continued support from the Malaysian government helps the infrastructure and plantation sector to survive longer after the IPOs.

It can be observed from the Table 2 that the technology and trading and services IPOs have the shortest survival period because some IPOs under these two sectors are delisted from the Market less than one year of their listing. These sectors are also among the sectors that record the lowest survival rate in seven years which is lower than the failure rate for the full sample $(86.8 \%)$. The one-year survival rate for technology, and trading and services IPOs are $97.67 \%$ and $98.55 \%$ respectively. The percentages of the firms that survive plunge to $83.6 \%$ for the technology sector and $80.62 \%$ for the trading and services sector seven years after the IPO. The finding regarding the technology IPOs supports the findings of Demers and Joos (2007) and Bhattacharya et al. (2009) who asserted that technology-related IPOs are more likely to report losses and accumulated deficits in the year prior to IPO. Due to the weak financial performance recorded by the technology companies prior to their listing, these companies have a higher probability of having financial distress which resulting in the failure during their public listing.

The construction sector reports the lowest survival rate. Within five years after the IPO, 22.22\% (10077.78) of the companies under the construction sector are delisted from the Market. However, the figure remains unchanged after seven years. Further investigations based on the data reveals that the main reasons for the failure of the construction sector are due to unsatisfactory financial conditions as well as merger and acquisition. As argued by Tserng et al. (2012), the unique characteristics of the construction companies may increase the probability of bankruptcy compared to other sectors. They pointed out that construction companies are characterised by producing unique projects, taking a longer period for the project to complete, higher uncertainty and risks linked to the construction activities, and they are commonly involved in various specific teams integrating different types of companies. Due to the nature of the business, they commonly have a problem of massive operating expenses and insufficient profit which subsequently lead to their bankruptcy (Arditi et al., 2000).

\subsection{Kaplan-Meier survival rates based on the listing board}

Previous studies have argued that companies that are listed in the Main Market are among the highquality companies because the listing requirement for the Main Market is more rigid than the listing requirement for other Markets (Espenlaub et al., 2012 and Thomadakis et al., 2012). Considering this argument, this study has divided the samples into the Main Market and the ACE Market, and it presumes that the survival rate of the Main Market IPOs is higher than the survival rate of those listed on the ACE Market. Based on the total of 352 companies listed between 2002 and 2010, 220 companies are listed in the Main Market, and 132 companies are listed in the ACE Market. Similar to the survival analysis presented in Table 2, the survival analysis according to the listing board is presented as a separate analysis for the full samples (PANEL A), across listing years (PANEL B), and across sectors (PANEL C). The results of the survival analysis for the two listing boards are presented in Table 3. 
PANEL A of Table 3 shows that the survival rates of the companies listed in the ACE Market are considerably lower compared to the survival rates of the companies listed in the Main Market. This indicates that the ACE Market IPOs have a higher probability to be delisted from the Market compared with the Main Market IPOs. Bearing in mind that the definition of survival used in this study, most IPOs that are delisted due to transfer to other Markets are included in the survivor's categories. Consequently, the risk of being delisted from the ACE Market is not due to the transfer to other Markets. The survival rate of the ACE Market IPOs is $91.6 \%$ after five years and the rate later drops to $83.8 \%$ after seven years of the companies being listed compared to $92.7 \%$ (5-years) and $88.6 \%$ (7-years) for the Main Market IPOs. This evidence is consistent with earlier arguments that the ability to survive after the IPO is higher for the Main Market IPOs because of their higher quality.

When the samples are split into years as shown in PANEL B, this section finds that the variations of the post-IPO survival rate is more pronounced in the ACE Market than in the Main Market. The logrank test of equality of the survival rates across the listing years indicates that the survival rate of the IPOs significantly varies between the markets at $10 \%$, taking a Chi-Square value of 12.56 and p-value of 0.0834 . The log-rank test across the listing years for the Main Market is insignificant (ChiSquare $=5.43$, P-value $=0.7104$ ). The results in PANEL B also reveals that more than half of the listed companies in 2005 are listed in the ACE Market, and they have better survival rate than the companies listed in the Main Market. Seven years of observation leaves only $84.9 \%$ of the Main Market IPOs that survive compared to $92.4 \%$ of the ACE Market IPOs which are listed in 2005.

PANEL $C$ shows the results of the survival analysis for the Main Market and the ACE Market across the sector categories. Based on the findings, the study finds that only four sectors are listed in the ACE Market. The four sectors are finance, industrial products, technology, and trading and services sectors. Focusing first on the Main Market, the results reveal that the construction sector has the lowest survival rates. The five years survival rate is $77.78 \%$, and the figure remains unchanged after seven years. The trading and services sector also report the lowest survival rates and times. IPO firms listed under the trading and services sector have a minimum survival time of less than one year. The one-year survival rate is $97.62 \%$, and this drops to $78.37 \%$ within seven years after the first day of listing. None of the IPOs under infrastructure projects, plantation, and technology are delisted from the Market within the seven years of their listing. As for the ACE Market, the results show that the technology sector has a higher probability of being delisted from the market especially after three years of listing. Table 3 indicates that a three-year survival rate is slightly reduced from $97.53 \%$ in one year to $96.3 \%$. About $13.72 \%(82.58-96.3)$ are delisted from the market in the following 4 years, with the remaining $82.58 \%$ of the IPOs survive after seven years of listing. However, the equality of survival rate across sectors is not significantly different in either listing board.

Overall, this section finds an effect of listing board on survival rates and times of IPOs. The cumulative survival rates over one through seven years after the IPO are consistently higher for the Main Market IPOs than the ACE Market IPOs for the full sample period. The Main Market IPOs have about 4.8 percentage point $(88.6 \%-83.8 \%)$ higher survival rate than the ACE Market IPOs after seven years. Similarly, each issue year shows a consistently higher survival rate for the Main Market IPOs except for 2002, 2005, 2008, and 2009. The survival rates for the 2002 and 2005 are lower for the Main Market IPOs four-years and two-years after listing respectively. The survival rates for 2008 and 2009 are equal to $100 \%$ for both markets. However, the pattern does not hold for comparison between the Main Market and the ACE Market across the issuers' sector. As noted previously, only four sectors (finance, industrial product, technology, and trading and services) are listed in the ACE Market. The survival rate of the ACE Market IPOs is higher for the finance, and the trading and services sectors, but lower for the industrial product and technology. This suggests that investing in the technology sector IPOs are riskier especially in those listed on the ACE Market. 


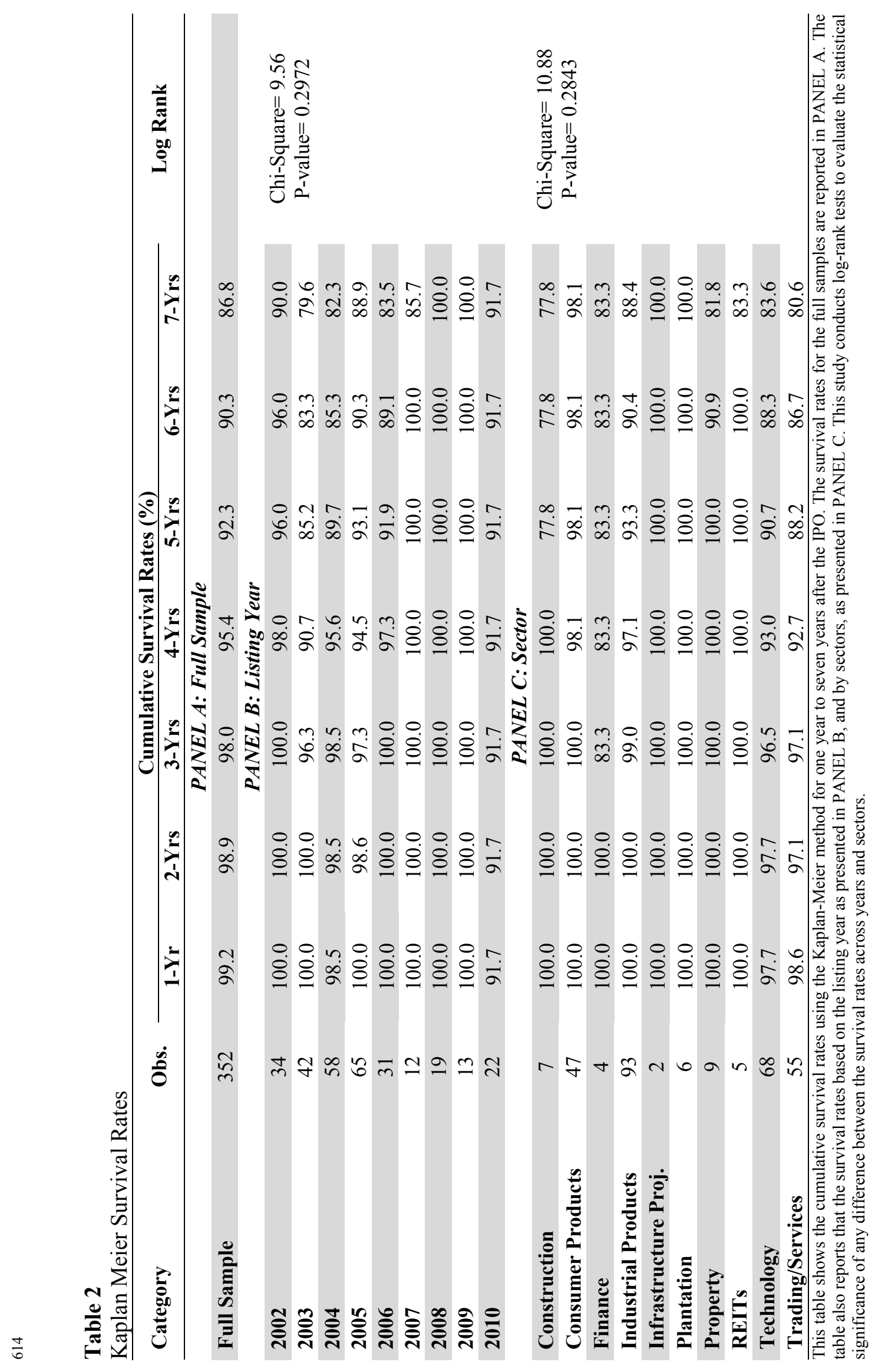




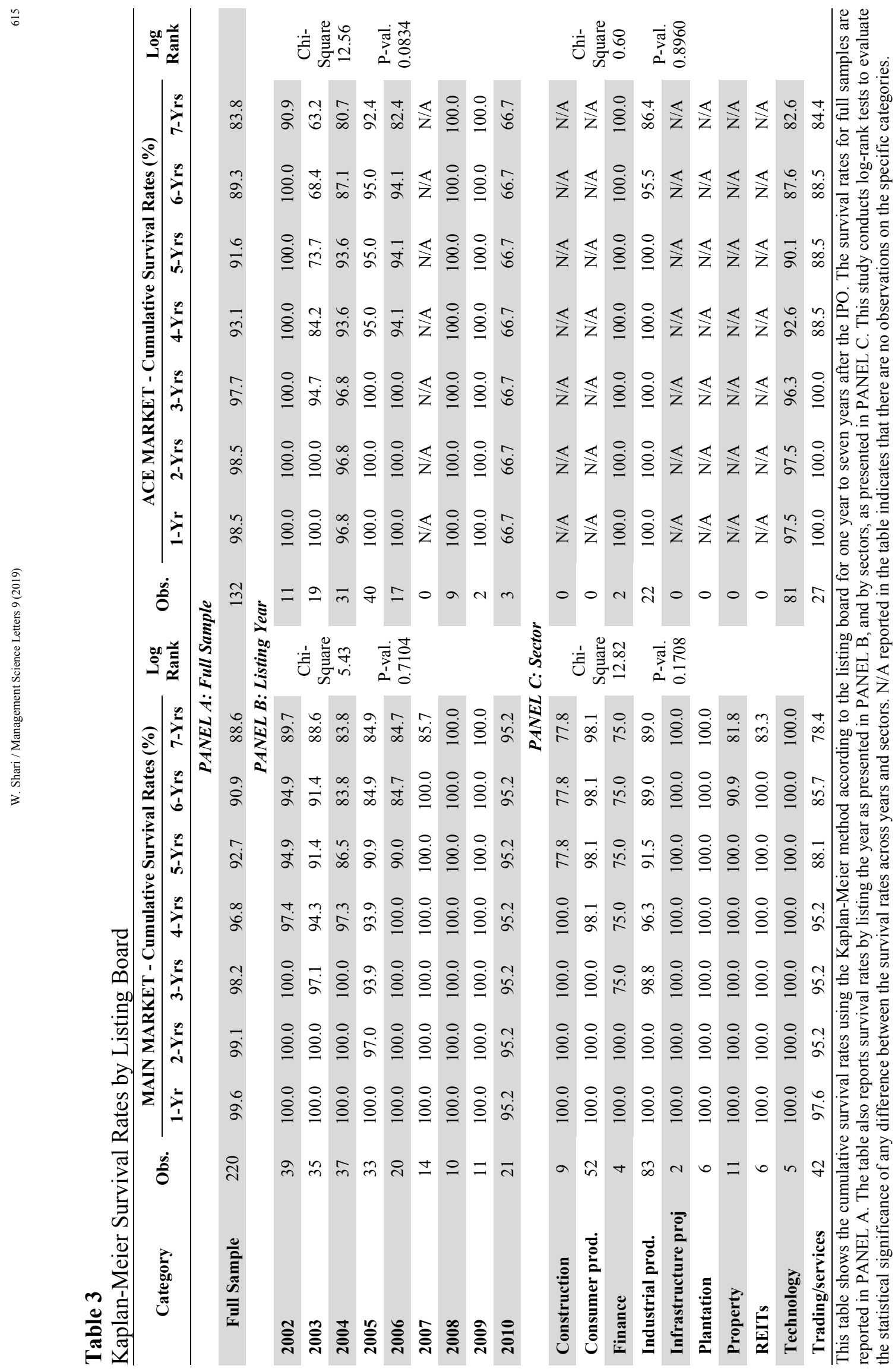




\subsection{Failure rate and delisting reasons}

Table 4 reports the failure rate of Malaysian IPOs due to the delisting reasons. In particular, this study disaggregates the delisting rates of one year, three years, five years and seven years due to delisting. The delisting rate is defined as 100 per cent minus the survival rate at a specific period. The delisting rates for the Main Market and the ACE Market are reported separately. Based on the samples, this study has identified five reasons for the IPO companies to be delisted from the market. These include the transfer to another market, failure to maintain the listing requirements, unsatisfactory financial conditions as well as merger and acquisition. However, an IPO that is delisted due to transfer to another market is excluded from the definition of failure which is consistent with Espenlaub et al. (2016) who defined survival as companies that continue to trade on the stock market or transfer to another stock market. Thus, only four reasons are considered in this analysis. Based on the inspection of the data, this study finds that from a total sample of 352 IPOs, 22 companies have been delisted from the market due to unsatisfactory financial conditions, 11 companies were involved in mergers and acquisitions, 9 companies failed to fulfil the listing requirements, and 4 companies proposed selective capital repayment.

Based on the Kaplan-Meier method, the seven years failure rate of 13.2\% (100-86.76) comprise 6.15\% for unsatisfactory financial conditions, $3.06 \%$ for merger and acquisition, $3.05 \%$ for failure to fulfil the listing requirements, and selective capital repayment accounts for $1.0 \%$. The findings suggest that the main reason for the failure of the Malaysian IPO companies listed between 2002 and 2010 was due to financial distress. Further observation of the failure rate reveals that the ACE Market IPOs experienced the lowest survival rate and time. After one year of listing, $0.7 \%$ of ACE Market IPOs have been delisted from the market due to unsatisfactory financial condition. This figure increases to $3.8 \%$ within five years and increases to $6.8 \%$ after seven years. The higher failure rate for the ACE Market is due to the majority of the IPOs listed on this Market being from the technology sector. The technology sector has been revealed by Demers and Joos (2007), and Bhattacharya et al. (2009) to suffer from weak financial positions before the IPOs which subsequently result in financial distress. Moreover, a lower listing requirement, such as no track record required from the issuer prior to being listed in the ACE Market, is another reason why the ACE Market IPOs are riskier than the Main Market IPOs (Teng, 2017). This finding also supports the evidence reported by Gregory et al. 2010 on the London Stock Exchange that Main Market IPOs are less likely to be delisted due to financial problems that lead to bankruptcy. $9.5 \%$ of AIM ${ }^{\mathrm{v}}$ IPOs enter bankruptcy by the end of the five years compared with only 3.6\% for the Main Market IPOs.

The finding reveals that the ACE Market IPOs are often delisted due to the issue of failing to meet its listing requirements especially after five years of listing. In comparison, 2.2\% of the ACE Market IPOs are delisted from the market after five years due to this reason and the percentage increases to $5.3 \%$ after seven years. Only $0.4 \%$ and $0.8 \%$ of the Main Market IPOs are delisted due to same reason after five and seven years of their listing respectively. This study anticipates that lower listing requirements of the ACE Market was the major reason that may contribute to the company's failure. Given their lower quality level, it is difficult for them to fulfil the obligation to continue to be listed. For instance, Section 8.03A (1) of the ACE listing requirement states that the issuer must maintain an adequate level of operation to warrant continued listing on the market (Securities Commission Malaysia, 2016).

It can be observed from Table 4 that the percentage of IPOs being delisted due to merger and acquisition are almost equal between the ACE Market and the Main Market IPOs. After seven years, 3.11\% of the Main Market IPO have been delisted due to this reason, and 3.01\% applies to the ACE Market IPOs. According to Krishnan et al. (2011), companies that are delisted due to merger and acquisition are not usually due to the inappropriate reasons. The table shows that $1.3 \%$ of the Main Market IPOs are delisted due to proposed selective capital repayments compared to only $0.7 \%$ for the ACE Market IPOs. 


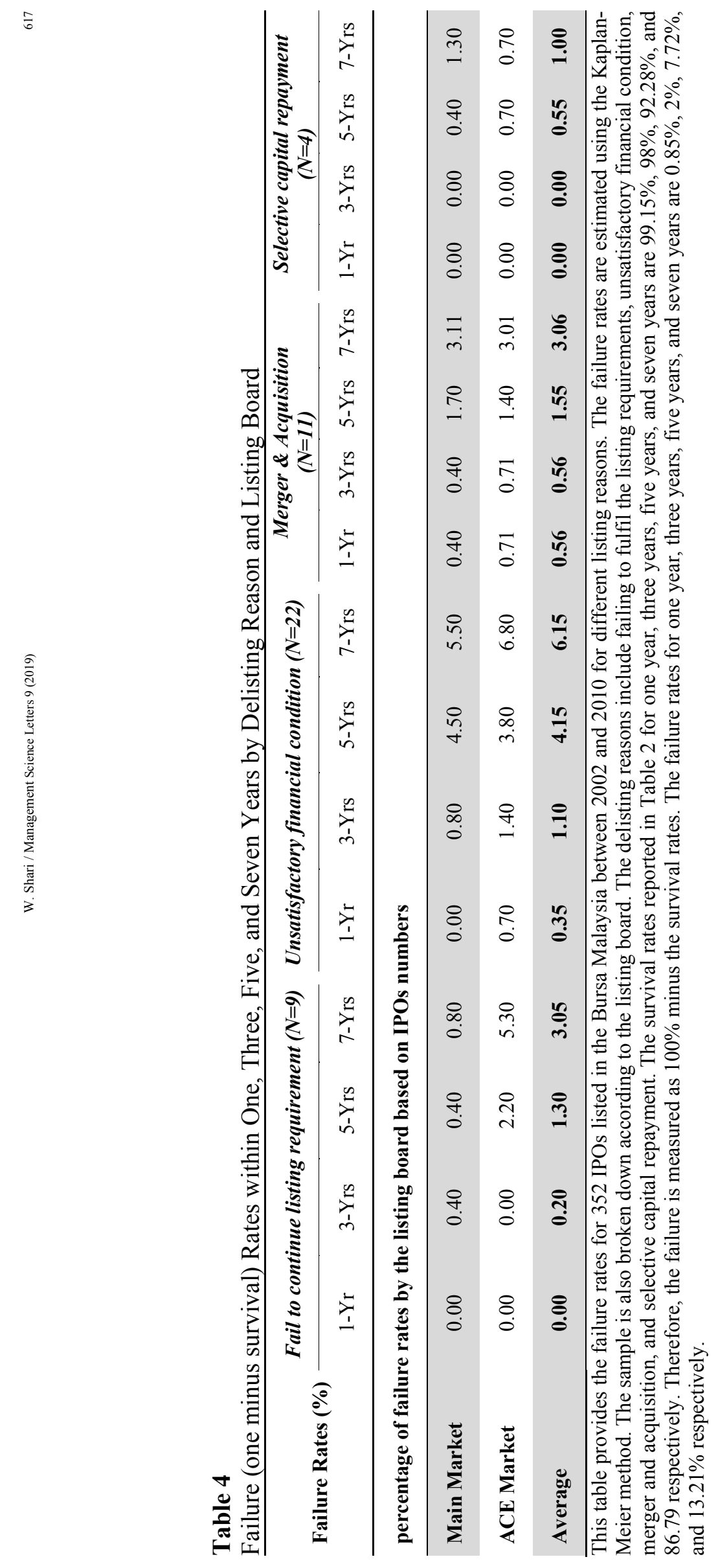




\section{Summary and conclusion}

Prior research has documented that more than $20 \%$ of the public companies were delisted from the market five years after their IPOs (see Hensler et al., 1997; Kooli and Meknassi, 2007; and Jain and Kini, 2008). This study has found that $0.85 \%$ of the public companies were delisted within one year after the IPO. The failure rate rises to $7.72 \%$ after five years which is lower than the statistics reported in previous studies based on the US, UK, and Canadian markets (See Table 1). Specifically, Hensler et al. (1997) reported that $28 \%$ of US IPOs were delisted after five years. Extending the observations up to seven years leaves only $86.8 \%$ IPOs continuing to trade in the market. This implies that out of 352 IPOs listed from 2002 to 2010, 46 companies (13.21\%) were permanently delisted from the market after seven years of their initial listing. This study, however, predicts that the lower failure rates reported in Malaysian IPOs can be explained by the implementation of the listing requirement framework under Practice Notes 17 (PN17) framework. ${ }^{\text {vi }}$ Companies that are involved in a financial problem will be classified under PN17 if they are listed in the Main Market and Guidance Note 4 (GN4) if they are listed in the ACE Market. Companies that fall within these categories will be suitably monitored by Bursa Malaysia in order to maintain the listing status in Bursa Malaysia.

Investigation of the delisting reasons reveals that unsatisfactory financial condition is the main contribution of the IPO companies' failure. Breaking down 13.21\% of failure rates into the delisting reasons indicates that $6 \%$ of the IPOs are delisted due to unsatisfactory financial conditions after seven years of being listed. Merge and acquisition account for $3.1 \%$ and failure to comply with the listing requirements accounts for $3.1 \%$ of the failure rate. Only $1 \%$ of the IPOs are delisted due to the proposed selective capital repayment.

Comparison of the survival rate between the Main Market and the ACE market reveals that the cumulative survival rates over one through seven years after the IPO are consistently higher for the Main Market IPOs than the ACE Market IPOs, suggesting that the ACE Market IPOs have a higher probability to be delisted from the Market compared to the Main Market IPOs. The ACE Market IPOs are often delisted due to the issue of failing to meet its listing requirements especially after five years of listing. While, the Main Market IPOs likely being delisted due to merger and acquisition.

Finally, this paper has provided some essential lessons to the investors and another stakeholder, who are interested in the survivability of IPOs, particularly in the Malaysian context. The finding suggests that it is important for the investors to pay more attention to the ownership structure of the companies as it provides a significant effect on the survival of the IPO firms in the Malaysian market.

\section{References}

Abu Bakar, N. \& Rosbi, S. (2016). Long term performance of Islamic share price for Initial Public Offerings ( IPOs ) in Malaysia: Evidence from Sharia - compliant companies listed on the Malaysian Stock Exchange ( 2006 - 2010 ). International Journal of Management Science and Business Administration, 2(6), 55-66.

Ahmad-Zaluki, N.A., Campbell, K. \& Goodacre, A. (2007). The long run share price performance of Malaysian Initial Public Offerings (IPOs). Journal of Business Finance and Accounting, 34(1-2), $78-110$.

Ahmad, W. \& Jelic, R. (2014). Lockup agreements and survival of UK IPOs. Journal of Business Finance \& Accounting, 41(5-6), 717-742.

Alhadab, M., Clacher, I. \& Keasey, K. (2015). Real and accrual earnings management and IPO failure risk. Accounting and Business Research, 45(1), 55-92.

Arditi, D., Koksal, A. \& Kale, S. (2000). Business failures in the construction industry. Engineering, Construction and Architectural Management, 7(2), 120-132.

Audretsch, D.B. \& Lehmann, E.E. (2005). The effects of experience, ownership, and knowledge on 
IPO survival: Empirical evidence from Germany. Review of Accounting and Finance, 4(4), 13-33.

Bhattacharya, N., Demers, E. \& Joos, P. (2009). The relevance of accounting information in a Stock Market Bubble: Evidence from Internet IPOs. Journal of Business Finance \& Accounting, 37(3-4), 291-321.

Bhattacharya, U., Borisov, A. \& Yu, X. (2015). Firm mortality and natal financial care. Journal of Financial and Quantitative Analysis, 50(1-2), 61-88.

Bradley, D. J., Cooney Jr, J. W., Dolvin, S. D., \& Jordan, B. D. (2006). Penny Stock IPOs. Financial Management, 35(1), 5-29.

Carpentier, C. \& Suret, J.-M. (2011). The survival and success of Canadian penny stock IPOs. Small Business Economics, 36(1), 101-121.

Caves, R.E. (1998). Industrial organization and new findings on the turnover and mobility of firms. Journal of Economic Literature, 36(4), 1947-1982.

Chancharat, N., Krishnamurti, C. \& Tian, G. (2012). Board structure and survival of new economy IPO firms. Corporate Governance: An International Review, 20(2), 144-163.

Chou, T.-K., Cheng, J.-C. \& Chien, C.-C. (2013). How useful is venture capital prestige? Evidence from IPO survivability. Small Business Economics, 40(4), 843-863.

Cleves, M.A., Gould, W.W. \& Gutierrez, R.G. (2004). An Introduction to Survival Analysis Using STATA Revised Ed., United State of America: Stata Press.

Corhay, A. (2002). The long run performance of Malaysian Initial Public Offerings ( IPOs ): Value and growth effects. Managerial Finance, 28(2), 52-65.

Demers, E. \& Joos, P. (2007). IPO Failure Risk. Journal of Accounting Research, 45(2), 333-371.

Economic Planning Unit (2006). Ninth Malaysia Plan, 2006-2010, Putrajaya, Kuala Lumpur. Available at: http://www.epu.gov.my/en/rmk/ninth-malaysia-plan-2006-2010.

Espenlaub, S., Goyal, A. \& Mohamed, A. (2016). Impact of legal institutions on IPO survival: A global perspective. Journal of Financial Stability, 25, 98-112.

Espenlaub, S., Khurshed, A. \& Mohamed, A. (2012). IPO survival in a reputational market. Journal of Business Finance \& Accounting, 39(3-4), 427-463.

Fama, E.F. \& French, K.R. (2004). New lists: Fundamentals and survival rates. Journal of Financial Economics, 73(2), 229-269.

Gregory, A., Guermat, C. \& Al-Shawawreh, F. (2010). UK IPOs: Long run returns, behavioural timing and pseudo timing. Journal of Business Finance \& Accounting, 37(5-6), 612-647.

Hamza, O. \& Kooli, M. (2010). Does venture capitalists reputation improve the survival profile of IPO Firms? SSRN Electronic Journal, (February), pp.1-36. Available at: https://papers.ssrn.com/sol3/papers.cfm?abstract_id=1857012.

Hensler, D.A., Rutherford, R.C. \& Springer, T.M. (1997). The survival of initial public offerings in the aftermarket. Journal of Financial Research, 20(1), 93-110.

How, J., Jelic, R., Saadouni, B., \& Verhoeven, P. (2007). Share allocations and performance of KLSE second board IPOs. Pacific-Basin Finance Journal, 15(3), 292-314.

Jain, B.A. \& Kini, O. (2000). Does the presence of venture capitalists improve the survival profile of IPO firms? Journal of Business Finance and Accounting, 27(9\&10), 1139-1183.

Jain, B.A. \& Kini, O. (2008). The impact of strategic investment choices on post-issue operating performance and survival of US IPO firms. Journal of Business Finance \& Accounting, 35(3-4), 459-490.

Jelic, R., Saadouni, B. \& Briston, R. (2001). Performance of Malaysian IPOs: Underwriters reputation and management earnings forecasts. Pacific-Basin Finance Journal, 9(5), pp.457-486.

Kooli, M. \& Meknassi, S. (2007). The survival profile of U.S. IPO issuers. The Journal of Wealth Management, 10(2), 105-119.

Krishnan, C. N. V., Ivanov, V. I., Masulis, R. W., \& Singh, A. K. (2011). Venture capital reputation, post-IPO performance, and corporate governance. Journal of Financial and Quantitative Analysis, 46(5), 1295-1333.

Naidu, G. (2008). Infrastructure Development in Malaysia, Available at: http://www.eria.org/publications/research_project_reports/images/pdf/PDF No.2/No.2-part2- 
7.Malaysia.pdf.

Paudyal, K., Saadouni, B. \& Briston, R.J. (1998). Privatisation initial public offerings in Malaysia: Initial premium and long-term performance. Pacific-Basin Finance Journal, 6(5), 427-451.

Schultz, P. (1993). Unit initial public offerings. A form of staged financing. Journal of Financial Economics, 34(2), 199-229.

Securities Commission Malaysia (2016). ACE Markat Listing Requirement. Securities Commission Malaysia. Available at: http://www.bursamalaysia.com/market/regulation/rules/listingrequirements/ace-market/listing-requirements [Accessed June 11, 2016].

Securities Commission Malaysia (2005). Rules and Regulations. Available at: https://www.sc.com.my/rules-and-regulations/.

Seguin, P.J. \& Smoller, M.M. (1997). Share price and mortality: An empirical evaluation of newly listed Nasdaq Stocks. Journal of Financial Economics, 45(3), 333-363.

Teng, L.J. (2017). ACE Market Listing Status Become More Valuable. The Edge Markets. Available at: http://www.theedgemarkets.com/article/ace-market-listing-status-becomes-more-valuable.

Thomadakis, S., Nounis, C. \& Gounopoulos, D. (2012). Long-term performance of Greek IPOs. European Financial Management, 18(1),117-141.

Tserng, H. P., Liao, H. H., Jaselskis, E. J., Tsai, L. K., \& Chen, P. C. (2011). Predicting construction contractor default with barrier option model. Journal of Construction Engineering and Management, 138(5), 621-630.

Vismara, S., Paleari, S. \& Ritter, J.R. (2012). Europe's second markets for small companies. European Financial Management, 18(3), 352-388.

Welbourne, T.M. \& Andrews, A.O. (1996). Predicting the performance of initial public offerings : Should human resource management be in the Equation? Academy of Management Journal, 39(4), 891-919.

Yang, C.-Y. \& Sheu, H.-J. (2006). Managerial ownership structure and IPO survivability. Journal of Management \& Governance, 10(1), 59-75.

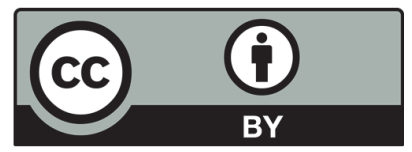

(C) 2019 by the authors; licensee Growing Science, Canada. This is an open access article distributed under the terms and conditions of the Creative Commons Attribution (CC-BY) license (http://creativecommons.org/licenses/by/4.0/).

\footnotetext{
${ }^{i}$ Investigation on the dataset of Malaysian IPO listed between 2002 and 2010 found twelve firms were delisted due to being transferred to other Market. These twelve firms were initially listed on the ACE Market and were later transferred to the Main Market due to better performance. Thus, treating these firms as survivors is reasonable.

ii We also measure the long-term performance of Malaysian IPOs listed between 2002 and 2010 and found that the Malaysian IPOs outperformed at 10.7\%) over the five-year period. These results are available upon request.

iii Seguin and Smoller (1997) defined penny stocks as stocks with an initial price below three dollars.

iv Bradley et al.(2006) used different definition of penny stocks than the one used in (Demers \& Joos, 2007). They defined penny stock as stocks that have an offer price equal to $\$ 5$ or less and the offer is not issued by an investment advisor.

${ }^{v}$ Similar with ACE Market, Alternative Investment Market (AIM) was developed for the small and high growth companies that could not meet the higher listing requirement of the Main Market.

vi PN17 is an amendment version of the PN4 and PN10 which were first introduced in 2001 by Bursa Malaysia. These framework was developed to ensure that sufficient disclosure was made about listed companies are in financial distress and to ensure that such companies take steps to efficiently restructure in order to address their unsatisfactory financial condition (Securities Commission Malaysia, 2005).
} 